\title{
Support for export as a non-standard Central Bank policy: foreign exchange interventions in the case of the Czech Republic
}

\author{
David KRIZEK ${ }^{*}$, Josef BRCAK ${ }^{* *}$
}

\begin{abstract}
Because of the crisis and, inter alia, to restore economic growth, some central banks have applied a non-standard monetary policy. In the case of the Czech Republic, this was in the form of foreign exchange interventions to support exports. Export is divided into sub-parts, which are examined by mainly using regression analysis in terms of changes in central bank indicators. The results show that foreign exchange interventions indeed had a positive impact on total exports, though considerably asymmetric. The standard instrument of the central bank, the Policy Interest Rate, has a much more significant impact on the industry.
\end{abstract}

Keywords: Central Bank; export; foreign exchange interventions; monetary policy; policy interest rate

\section{Introduction}

Given the relatively new situation created by the application of unconventional monetary policies, this paper brings new and updated findings concerning this area with regard to the impacts on the national economy of the Czech Republic. Here, the foreign exchange intervention method was used and, as in other countries using non-standard monetary policy, the aim was to restore price growth as well as GDP growth. Given the fact that it is a significantly open economy with the great importance of exports also determined by the exchange rate, it is more important to address the impacts of this market-distorting policy. Furthermore, it should be noted that while this is a case of one country, there is manipulation, both open and covert, in many countries of the world and those are economically significant. The main aim of this article is to verify the positive impacts of foreign exchange interventions on exports as a whole as well as on individual export

\footnotetext{
${ }^{*}$ David KRIZEK is Assistant Professor at Czech University of Life Sciences Prague, Czech Republic; e-mail: krizekd@pef.czu.cz.

** Josef BRCAK is Associate Professor at Czech University of Life Sciences Prague, Prague, Czech Republic.
} 
industries. From this perspective, this is a unique approach, as the channel through which the primary goal is to be achieved is analysed. If this channel is inoperative, impacts cannot be expected.

It is difficult to launch a foreign exchange intervention where there is a standard flexible regime, involving transparency, communication, but also high implementation costs (Fratzscher, 2019). Is it so necessary to ask whether this is necessary and whether these costs are necessary? Furthermore, it is not usual to use foreign exchange intervention to affect one component of GDP. As Adler (2011) points out, half of central banks primarily dampen exchange-rate volatility, the remaining half were motivated in the past primarily by accumulation of foreign exchange reserves, for example Chile, Mexico or Turkey. Asian economies hit by the 1997-1998 financial crisis are examples of large-scale interventions to this end. These accumulated reserves were then used again by Korea and Malaysia, for example, to further influence the exchange rate during the crisis that began in 2008 (Chutasripanich, 2015).

However, it is extremely difficult to estimate an equilibrium exchange rate and any blow against it is extremely risky and can dent a central bank's creditworthiness. Again, the question is why is the central bank taking this approach, and is it worth the risk? This work seeks to answer this question, providing guidance on whether or not it is worth operating on a product, not just an exchange rate. This is still the case in the current long-standing conditions of particularly loose monetary policy.

The motivation for writing this article is a precarious situation from the perspective of the effects of non-standard central bank policies. The last decade has seen a significant shift from standard monetary policy to areas of non-standard monetary policy that are not described and that do not offer answers to questions. For example, is efficiency really as declared? What are the long-term effects? Isn't it just a drug for stimulation that will have to be delivered over and over again?

The contribution to the present literature, then, is that our work seeks to synthesize monetary policy and the real economy in the sense that the effects of monetary policy have consequences for the components of GDP. According to the basic economic literature, in the case of foreign-exchange intervention, they are then, to influence exports through the exchange rate that the central bank seeks to influence at a stable one level. Nevertheless, it must be remembered that these interventions were used at an exceptionally unusual time and during one of the most serious recessions in modern history. Was it appropriate to use these unusual measures? And did they really have the effect they were supposed to have? In the literature, the impact on financial markets, and not on product components, is usually sought. Anyway, nowhere in the literature is the emphasis on the small open economy. When examining central bank policies such as the FED, the BOE and the like, different impacts are identified. But other central banks that pursue their monetary policies cannot be ignored. 
This paper will first look at the theoretical background. Based on this, hypotheses will be formulated in the following section of Data and Methodology. To test them, the parameters and methods used to process them will be defined. This will be followed by the analysis itself in the Results chapter. The results obtained will be presented in tables and comments. In the Discussion chapter, the results will be confronted with the hypotheses and other papers that deal with this topic. A short summary will be provided at the end. The aim is to examine the effects of standard and non-standard monetary policy on the export sector. Based on this, which policy is more effective will be determined.

\section{Literature review and research hypotheses}

A thorough analysis can identify the ambiguous impacts in the short term and long term. In the short term, the effects on the national economy, i.e. price levels and economic growth, can be assessed and differentiated, with an emphasis on export industries and changes in foreign trade. In the long run, Colacito (2011) addressed manipulation of the real exchange rate, for example, on this issue using stochastic discount factors.

In the standard situation for a small open economy, a flexible exchange rate, as understood in mainstream economic theories, functions as a mechanism for balancing relative prices between countries. It responds to shocks, which are standardized on both the demand and supply side and compensates for these fluctuations. This fluctuation is natural and is a reaction of the free market. Nowadays, it is quite common for developed countries and their central banks to maintain a free exchange rate. However, there are still situations where the central bank, in democratic societies led by its primary objective, is motivated to actively influence and change the natural market exchange rate. In addition, as stated in Cavallino, "the volatility of international capital flows has increased substantially since the global financial crisis of 2008-2010" (2019, p. 2). The impact of interventions on the volatility of exchange rates, for example, has been examined by using a multivariate GARCH model with time varying conditional covariance (Beine, 2004). On the contrary, by using the Exponential GARCH $(1,1)$ framework, Cicek (2014) refutes the influence of interventions on volatility and hence, on the level of the exchange rate. In general, foreign exchange intervention is defined as the purchase or sale of foreign assets. By purchasing, the central bank increases its foreign exchange reserves. In this way, it affects domestic currency assets, whose supply increases because of intervention.

Unconventional monetary policy does not only affect total exports. It is thus possible to further identify the emergence of asymmetries in response to this policy and changes in behaviour and market access. Based on the results generated, effective recommendations can be made, which may relate to the specification of the quality of the implementation of unconventional measures, or to assess their 
effectiveness and impact on free market competition, as well as for standard monetary policy in times of recession.

If the export industry, which is one of the most important components of the gross domestic product (GDP), is affected, it can be assumed that it will influence other sectors and components of the GDP. This paper approaches the issue in an innovative way as it seeks to cover not only the overall impacts over a longer period, but also the actual impacts on individual export groups of commodities. It can be assessed whether unconventional monetary policy had to be used or not, and the consequences for the national economy can be identified. Its necessity is advocated, for example, by Montoro (2016) based on the relationship between the central bank, foreign investors and the impact on volatility, and risk aversion using the dynamic stochastic model. Most similar foreign exchange intervention studies, such as Korinek (2011), Farhi (2012), and Blanchard (2015), deal primarily with the impact on capital flows and the financial side of the matter, including the impact on financial markets.

The standard monetary policy used by the central banks of most developed countries is based primarily on the concept of a new consensus. It synthesizes the teachings of J. M. Keynes, improved by his successors and neoclassical economics schools. The main instrument was interest rates, always determined according to the Taylor rule on the relationship between the nominal interest rate, the inflation gap and the GDP (see, for example, Taylor (2000) and Cottrell (2018)).

However, these normal regulations were not sufficient during the financial and subsequent economic crisis, and many central banks thus adopted an unconventional monetary policy. It took different forms, but the goal was always common. Stable price level growth and, at the same time, support for economic growth. Fawley (2013) states that quantitative easing is a kind of policy that unusually increases the monetary base. Based on this definition, foreign exchange interventions are a special form of quantitative easing. It is done either by releasing money or by lending. In the case of the purchase of assets by the central bank, the first option occurs if the central bank improves the conditions for obtaining loans, which subsequently increases the currency base, it is the second option, i.e. the release of loans.

Based on the information provided by Chodorow-Reich (2014), related to quantitative easing, it can be said that this is a long-term interest rate target based on:

- the purchase of state bonds,

- the purchase of securities,

- the purchase of mortgage-backed securities,

- the purchase of securities from other public institutions,

- the purchase of additional assets that may affect the future value of long-term interest rates.

However, quite obviously, central bankers focused on short-term goals. The evaluation of their effectiveness is the subject of many expert articles. In the vast majority, the focus is primarily on the Fed, the BoE or the ECB and the effect of spill 
over policies or the issue of ending quantitative easing programs, such as Palley (2014). As stated by Haas, "quantitative easing has little effect at the level of macroeconomic indicators. It was neither expansionary nor deeply harmful, but merely ineffectual"' (2017, p. 26).

Foreign exchange interventions were adopted because the short-term interest rates are zero and the basic policy - the domestic policy interest rate does not work. In order to fully fulfil the assumption that foreign exchange interventions are a form of quantitative easing, their impact on long-term interest rates would need to be analysed. This can be assumed, since after the adoption of foreign exchange interventions by the Czech National Bank, long-term interest rates decreased by 131 basis points during one year, while in the previous period there had been an increase of 26 basis points. No significant fluctuations occurred during the interventions. After the end of this policy, the long-term interest rate increased again by 94 basis points within one year and was again close to its original value before interventions (Czech National Bank, 2019). Interest rates also affect exchange rates. However, foreign exchange interventions fix the exchange rate and, in this way, any volatility is excluded. Thus, the currency was devalued by the central bank policy.

After leaving the foreign exchange intervention regime, there is a gradual appreciation to the original level before the intervention. However, further investigation of this issue is possible elsewhere. This article deals with the primary impacts of foreign exchange interventions on the export condition. The unconventional foreign exchange intervention policy has a direct effect on exports, which the central bank primarily influences through its two channel policy - the direct purchase / sale of foreign exchange assets and the expectations channels (Dominguez, 1993), which may lead to speculation, uncertainty in the market, etc. It acts by biasing the market's competitive exchange rate equilibrium, whose importance for economic growth is illustrated by many studies, such as Rapetti (2013), Frenkel (2014), Damill (2015) on the case of Argentina or Missio (2015). However, as Guzman (2018) notes, there is currently no classical market equilibrium, as there is a large number of regulations and instruments affecting market equilibrium, such as central bank interest rates. However, it is evident that there are more significant impacts on market agents when applying unconventional monetary policy, also because of the amount of money used to do so. Therefore, it is necessary to reflect on the short as well as on the long term consequences. Longterm eased monetary policy and unconventional measures are the result of shifting investment into higher-risk, higher-yield derivatives. In addition, direct support to debt growth due to better lending conditions reduces the incentive to undertake structural reforms and to balance budgets. Zamrazilová (2014), who rather sees the causes in the significant uncertainty caused by the considerably eased monetary policy, reached similar conclusions. This uncertainty may also be reflected in the behaviour of exporters who are preparing for an uncertain future and behave cautiously, postponing expansion, investment, etc. On the other hand, Karnit (2013) 
supports the idea that intervention can mitigate the negative effects of the crisis on exports and imports. In the long run, both factors are highly risky and create conditions for a further, even more pronounced, economic downturn. Another issue is the extremely high monetary base. Here, either a gradual dissolution into the economy or uncontrollable inflation will occur.

Another consequence is the distortion of financial asset prices, the creation of a price bubble and the impossibility of determining the price achieved by free market competition based on supply and demand. Bauer and Rudebusch (2014) do this through several channels, one of which is market uncertainty about non-standard monetary policies and their possible future developments, as evidenced. The second is due to the quantitative easing of supply reduction for the purchase of financial assets and thus the increasing pressure to change their price, such as Gagnon et al. (2011) demonstrate. This increases capital transfers to less developed economies and increases risk for profit.

There are a number of papers: Daude (2016), Adler (2019), Fratzscher (2019) or Wang et al. (2020) dealing with foreign exchange interventions and their effects on the foreign exchange market, but there is a fundamental shortcoming in the literature that would provide a detailed analysis of the impacts on the real economy. Therefore, this article aims to examine one of the components of GDP, i.e. exports, with regard to a detailed analysis of this indicator.

\section{Methodology}

The basic hypotheses of this article are:

- H01: the application of unconventional monetary policy can have a positive impact on the export industry as a whole;

- H02: unconventional monetary policy supports export industries asymmetrically and causes a non-market advantage to certain groups;

- H03: the standard monetary policy instrument represented by the interest rate has a significant impact on the export industry.

In the case of hypothesis H01, it is examined whether one of the main objectives of the Czech National Bank, justified in applying a non-standard monetary policy of foreign exchange interventions as a form of quantitative easing, i.e. support for the export industry, was actually fulfilled and whether this could thus stimulate the economy and the related rise in the price level. That is, whether there is a direct relationship between the growth of the central bank's foreign exchange reserves and the growth of individual export groups. This claim is confirmed by Fukuda (2016) by relying on the construction of a simple export function based on the example of Japan after the implementation of unconventional monetary policy. In contrast, using the gravity model, Rose (2018) argues that there is no evidence of export growth using unconventional monetary policy and that there is even a decline in some cases. The H02 hypothesis examines whether the effects of foreign exchange interventions, 
irrespective of whether they are directly positive or negative, can be identified across individual groups of the export sector and whether these implications of nonstandard monetary policy affect them all symmetrically. Confirming the hypothesis would prove that foreign exchange interventions, respectively quantitative easing, over a given time horizon, stimulated exporters irrespective of the export industry and, thus, did not favour some exporters or interest groups over others. Using regression coefficients and the strength of the relationship, it will be possible to formulate the conclusion whether any export industry is supported more compared to are. Alternatively, whether some sectors are disadvantaged compared to others. Monetary policy transmission causes asymmetry of impacts and some sectors are more susceptible to this. This is demonstrated, for example, by Georgiadis (2015) based on the use of the global VAR model and the euro area states in a previous work by Georgiadis (2014). For its part, based on the Bayesian Time-Varying Parameters FAVAR, Serati (2019) confirms that the transmission mechanism causes asymmetries even when unconventional currency measures are applied or eliminated.

The last hypothesis $\mathrm{H} 03$ deals with the influence of the standard monetary policy instrument. The assumption is that the reduction of interest rates through the transmission mechanism promotes export and, thus, an indirect relationship between the interest rate and the monitored export groups can be assumed. For example, Lutz (2015) discusses the similarity between the effects of conventional and unconventional, based on investor behaviour, monetary policy. Inoue (2018) formulates similar conclusions, using its own model of VARs with fictional shocks. However, the work shows that product support and inflation resulting from unconventional monetary policy peak within about 1 year and subsequently decline and the effect is significantly reduced.

Hypotheses are tested using the correlation and regression method. The first step is correlation analysis between changes in the variables growth ratios. This will characterize the extent to which the export industry is dependent on the three variables describing the behaviour of the central bank. Thus, it is described whether these interrelations are real and correspond to the assumption of interrelation. The Pearson correlation coefficient method is used. With respect to real data development and its smoothing by logarithmization, there will be no possible distortion due to non-standard outlying observations. The Pearson coefficient is then calculated based on covariance and standard deviations (for example, see Hendl, 2012, p. 253).

Then, classical regression analysis on the given data is used. Regression coefficients are identified, which continues to help to describe the issue. The given equation is used:

$$
V E X_{n t}=F I R \beta_{1 t}+T A \beta_{2 t}+P I R \beta_{3 t}+\alpha+\varepsilon,
$$


where parameters $[F I R],[T A],[P I R]$ are listed below. Parameter $[\varepsilon]$ represents the error component and parameter $[\alpha]$ a random component, respectively, the regression constant, or the point at which the inserted line intersects the y-axis. Parameters $\left[\beta_{1}\right]$, $\left[\beta_{2}\right]$, $\left[\beta_{3}\right]$, that are the slopes of the regression curve, or vectors, show to what extent the dependent variables change if the independent variable changes. The dependent variable is characterized as $\left[V E X_{n t}\right]$, where $[n]$ takes values from 1 to 10 , depending on the export group, as shown in Table 1 and the number used indicates the export group.

Table 1. Model description

\begin{tabular}{|c|c|c|c|c|c|}
\hline & $(01)$ & (02) & (03) & $(04)$ & $(05)$ \\
\hline Indicator & $\begin{array}{l}\text { Food and } \\
\text { Live } \\
\text { Animals }\end{array}$ & $\begin{array}{c}\text { Beverages } \\
\text { and Tobacco }\end{array}$ & $\begin{array}{c}\text { Crude } \\
\text { Materials, } \\
\text { Inedible, } \\
\text { Except } \\
\text { Fuels }\end{array}$ & $\begin{array}{l}\text { Mineral } \\
\text { Fuels, } \\
\text { Lubricants } \\
\text { and Related } \\
\text { Materials }\end{array}$ & $\begin{array}{l}\text { Animal and } \\
\text { Vegetable } \\
\text { Oils, Fats } \\
\text { and Waxes }\end{array}$ \\
\hline \multirow[t]{2}{*}{ Abbreviation } & V1EX & V2EX & V3EX & V4EX & V5EX \\
\hline & $(06)$ & $(07)$ & $(08)$ & (09) & (10) \\
\hline Indicator & $\begin{array}{c}\text { Chemicals } \\
\text { and } \\
\text { Related } \\
\text { Products }\end{array}$ & $\begin{array}{c}\text { Manufactured } \\
\text { Goods } \\
\text { Classified } \\
\text { Chiefly by } \\
\text { Material }\end{array}$ & $\begin{array}{l}\text { Machinery } \\
\text { and } \\
\text { Transport } \\
\text { Equipment }\end{array}$ & $\begin{array}{c}\text { Miscellaneous } \\
\text { Manufactured } \\
\text { Articles }\end{array}$ & $\begin{array}{c}\text { Commodities } \\
\text { and } \\
\text { Transactions } \\
\text { not } \\
\text { Classified } \\
\text { Elsewhere in } \\
\text { the SITC }\end{array}$ \\
\hline Abbreviation & V6EX & V7EX & V8EX & V9EX & V10EX \\
\hline
\end{tabular}

Source: authors' representation based on Czech Statistical Office (2019)

The table shows the division of exports into categories by industry and the abbreviations that are used in this paper.

Each number from 1 to 10 indicates one category. Parameter $[t]$ represents time index. Furthermore, from these values, it is possible to determine the coefficient of determination $\left[R^{2}\right]$ indicating the quality of the output from the regression analysis, or variability of the tested indicators. Table 1 describes the indicators used in this article in the position of dependent variables, including their abbreviations used in the data processing itself. 


\section{Data}

Numerical data in a sequence arranged over time will be subject to empirical analysis including their chaining, smoothing, trend identification and cyclicity. Correlation and regression analysis will be used for deeper research of relevant secondary macroeconomic indicators of the national economy and industry, examining the relationship between selected variables, strength and dependence rates between them, and their growth ratios, respectively. Furthermore, we assume that the influence of the previous period gradually disappears over time due to the complexity of the examined variables, which are linked to the national economy and its identity and thus one is not able to influence another in the long term. If the zero hypothesis of non-existence is not rejected, the analysis will be complemented by an Autoregressive Integrated Moving Average (Arima) process to eliminate the effect of consecutive periods (AR1), and possibly by a time delay.

If we have a combination of $\mathrm{AR}(\mathrm{p})$ and $\mathrm{MA}(\mathrm{q})$ processes, an equivalent MA model with a sufficient number of q elements of interference can be found for each p-order AR model. The aim was to find the smallest number of $p$ and $q$ elements needed to make a satisfactory prediction of the time series. There is currently a number of estimation procedures and, due to their considerable complexity, IBM SPSS software has been used to estimate model parameters.

This article is based primarily on the time series related to the Czech export industry, obtained from the database of the Czech Statistical Office, which is based on the methodology established by the European Union and Eurostat. They are selected by industry and so it is possible to monitor the development of exports by commodity in detail. These make up the export itself. This is complemented by the time series dealing with the monetary policy of the central bank, obtained in this case from the database of the Czech National Bank. The reporting period includes the interval from January 2008 to January 2019. All data are adjusted to examine their growth ratios, not nominal values and January 2008 is used as the basic value. The data are monitored on a monthly basis, which allows working with a sufficient number of observations for macro-level data, i.e. 133 numerical data for each export group. Based on the literature review and on the primary focus of this article, the following hypotheses are set. These will be evaluated based on the testing of selected indicators and variables and will make it possible to evaluate the foreign exchange interventions' importance for the export industry.

The export sector is divided into 10 groups according to the nature of the export materials, processed according to the methodology of the cross-border concept. The primary source of this data is the customs authorities; then, the data is usually processed and presented by the national statistical authority. In this article, primary attention is paid to export. By definition of the institution providing the data used, this is defined as "the value of goods dispatched abroad which have crossed the border for the purpose of leaving them permanently or temporarily abroad. Thus, 
total exports consist of shipments to EU countries and exports to countries outside the EU" (CSO, 2019). The division itself respects the international trade classification established by the United Nations (UN) - Standard International Trade Classification (SITC), Revision 4.

Given the relatively high fluctuation caused by the cyclicality of the business cycle and the seasonality which distorts the time series, the original data in thousands of dollars is adjusted by using a natural logarithm. The time series are thus cleaned up and significantly eliminated. The data modified in this way are displayed for the reference period in Figure 1.

Figure 1. Development of export values groups in the period January 2008 to January 2019

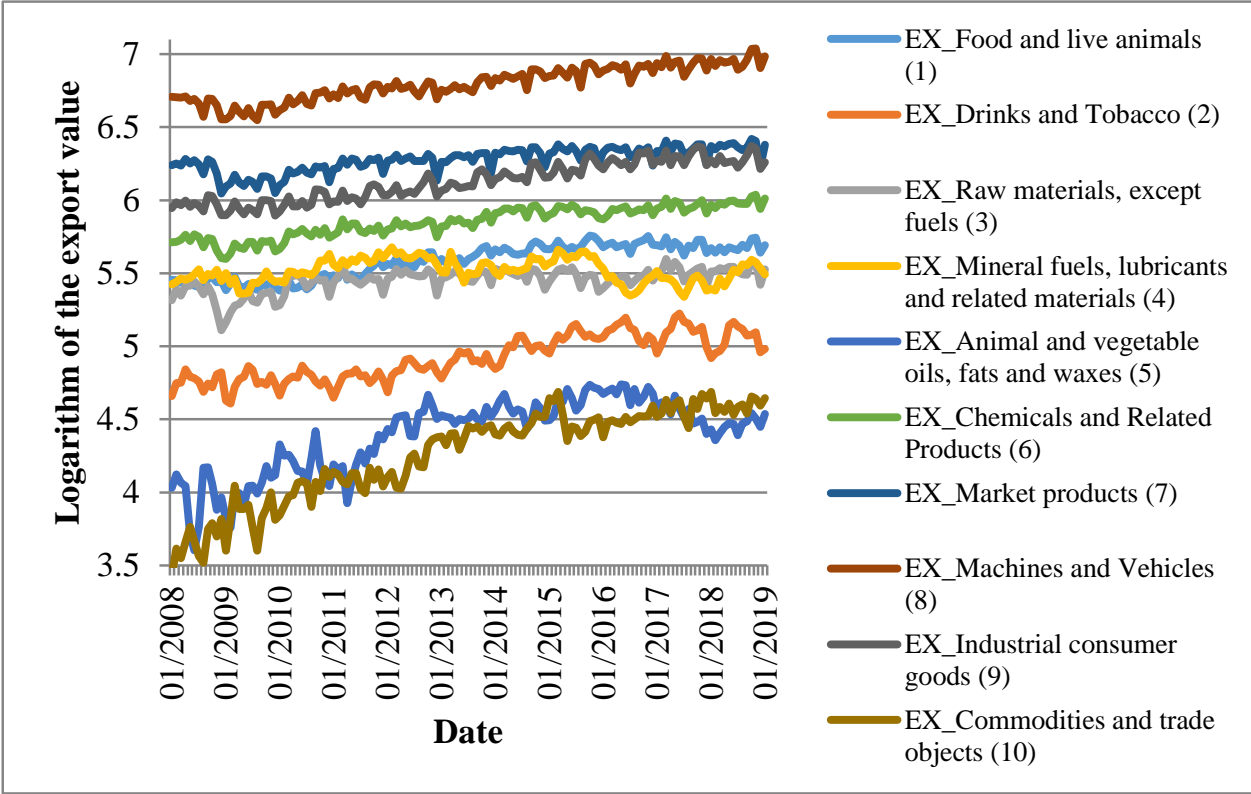

Source: Authors' representation based on Czech Statistical Office (2019)

The legend lists them by value at the end of the reference period. The measured value of the exported goods is subsequently adjusted as the growth ratio and January 2008 is used as the basic value. Furthermore, indicators representing central bank policy are selected. These are the basic monetary policy instruments that best reflect the monetary policy of the central bank. Furthermore, foreign exchange interventions increase the balance sheet of the central bank and thus provide a unique opportunity to use this data as an indicator reflecting foreign exchange interventions. These will then form independent variables when examining the interrelationship with external trade indicators related to exports. These are the 
Central Foreign Exchange Reserves $[F E R]$. International reserves are the Czech National Bank's liquid external assets in convertible currencies. International reserves include monetary gold (gold deposits and gold swaps), special drawing rights (SDR's), the reserve position in the International Monetary Fund (IMF) and other reserve assets (i.e. currency and deposits, securities, financial derivatives, other claims). Czech National Bank reports international reserves in a form of data template created by IMF (Guidelines for a Data Template on International Reserves and Foreign Currency Liquidity) consistent with the BPM6 manual (Balance of Payments and International Investment Position Manual, 6th edition). The CNB's databases are sources for ascertainment of the International Assets (the Reserves Data Template). The template is processed on a monthly basis and is posted on the 7th day of the month after the reference period (preliminary data) on the CNB's internet website. The preliminary data are revised every following month (Czech National Bank, 2019). In addition, Total Assets [TA] which, due to the growth of Foreign Exchange Reserves, exhibits similar behaviour, is also examined as a control variable, as this value is also increasing, but at a more constant pace or more smoothed trend. The development of both indicators is shown in Figure 2.

Figure 2. Development of selected central bank indicators in the period January 2008 to January 2019

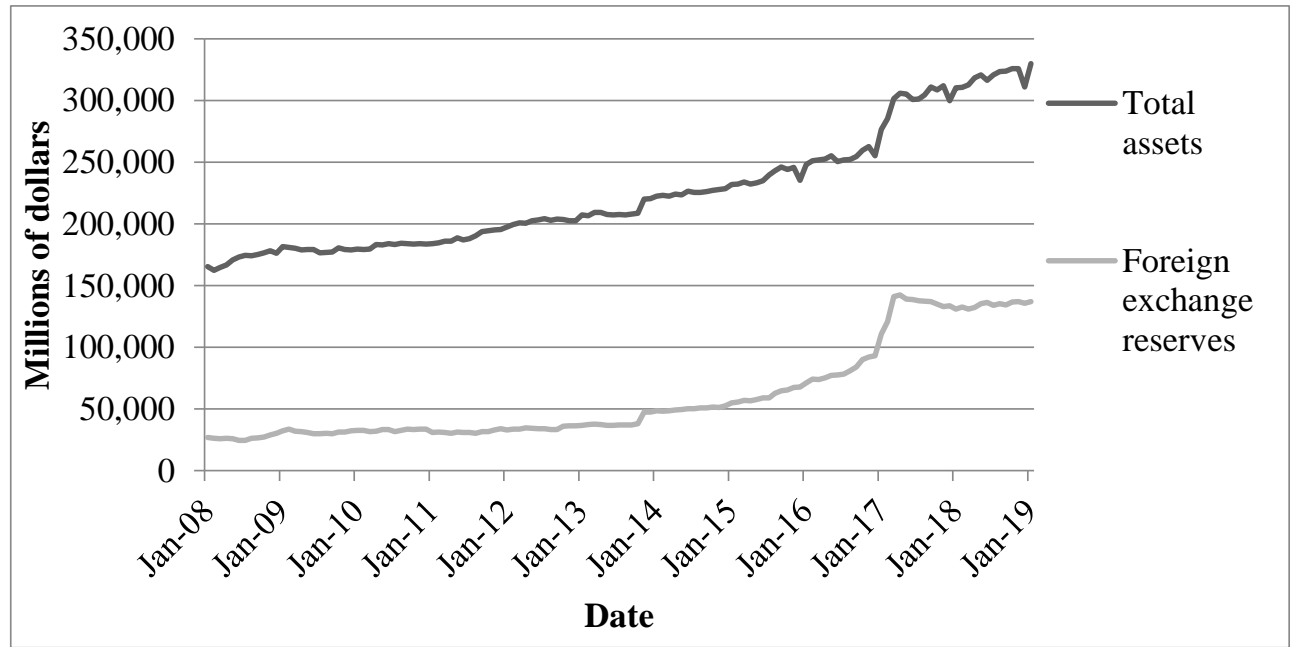

Source: Authors' representation based on Czech National Bank (2019)

Harmonised monetary statistics are compiled in line with the ECB Regulation concerning the balance sheet of monetary financial institutions sector. The aim is to provide the European Central Bank with a comprehensive statistical survey of monetary development in the participating member states, which are considered to 
form a single economic area. The statistics include stocks data on aggregated financial assets and liabilities, flow data concerning credits and flow data concerning securities. As one of the accession countries, as part of the harmonisation procedure, the Czech Republic has undertaken to compile a harmonised balance sheet for the Monetary Financial Institutions (MFIs) sector in accordance with the ECB Regulation and with the methodology for non-member states of the euro area. The harmonised monetary statistics are compiled from data from monetary and banking statistics statements and the CNB's own calculations for the consolidated MFI balance sheet (Czech National Bank, 2019).

The share of $[F E R]$ at the beginning of the period under review is approximately $16 \%$ of TA, reaching $42 \%$ at the end of the period under review. The last variable characterizing the central bank is the key monetary policy instrument, i.e. the Policy Interest Rate $[P I R]$. The main monetary policy instrument, Repo rate - 2 weeks is the maximum limit rate at which banks' bids can be satisfied in the CNB's 2 weeks repo tenders. Decisions on the level of interest rates are taken by the Governing Board and are announced in the form of official information of the CNB (Czech National Bank, 2019).

\section{Results}

Acquired and adjusted time series are first analysed by using basic statistical variables. This is because any deviations or unexpected variability that could affect further investigation needs to be identified. Table 2 shows the absolute values of each variable in their minimum and maximum values, as well as the average and its standard deviation. The standard deviation is the average deviation from the average. In other words, it is the square root of scattering.

Table 2. Descriptive Statistics

\begin{tabular}{lcrrrr}
\hline & N & Minimum & \multicolumn{1}{c}{ Maximum } & \multicolumn{1}{c}{ Mean } & \multicolumn{1}{c}{ Std. Deviation } \\
\hline V01EX & 133 & 5687216 & 13543531 & 9343007.38 & 2331729.150 \\
\hline V02EX & 133 & 958075 & 3953321 & 2080611.08 & 734276.524 \\
\hline V03EX & 133 & 3029755 & 9341326 & 6781358.89 & 1166435.666 \\
\hline V04EX & 133 & 5132558 & 11228231 & 7882215.97 & 1456806.186 \\
\hline V05EX & 133 & 94504 & 1295645 & 667719.90 & 316759.794 \\
\hline V06EX & 133 & 9341965 & 25725112 & 17264549.70 & 3950595.057 \\
\hline V07EX & 133 & 26164081 & 61937885 & 45547363.56 & 8245217.893 \\
\hline V08EX & 133 & 83392376 & 257443460 & 153409932.89 & 40499194.235 \\
\hline V09EX & 133 & 18560350 & 55556828 & 33067657.35 & 10040932.398 \\
\hline V10EX & 133 & 63119 & 1152736 & 533075.74 & 303723.172 \\
\hline
\end{tabular}

Source: Authors' representation based on Czech Statistical Office (2019) 
The table shows basic statistical indicators characterizing individual export groups by industry. These are number of observations, minimum value, maximum value, mean and standard deviation. The monitored indicators can be further assessed according to their nominal values and four export groups can be identified according to their importance. Only one indicator, namely the high export group Machinery and Transport Equipment (08), which is dominant, represents the first group. The second group is the measured mean levels found in the Manufactured Goods Classified Chiefly by Material (07) and Miscellaneous Manufactured Articles (09) indicators, followed by the lower value Chemicals and Related Products (06). The penultimate group with a smaller share of total exports consists of the indicators Food and Live Animals (01), Beverages and Tobacco (02), Crude Materials, Inedible, Except Fuels (03), Mineral Fuels, Lubricants and Related Materials (04). The smallest and negligible group consists of Animal and Vegetable Oils, Fats and Waxes (05) and Commodities and Transactions not Classified Elsewhere in the SITC (10).

The latter group will be excluded in the regression investigation and will no longer be considered. This is because of the low value involved in exports, but also because of the high standard deviation from the average. This high variability is not suitable for further investigation and, in the case of the last group, after deducting the standard deviation from the mean twice, we get a negative number and the average with the standard deviation is thus used incorrectly. It is therefore advisable to use the median in case of further investigation of this variable.

Other export groups do not report problematic data breakdowns. This is continuous data. Therefore, the Pearson correlation coefficient can be used and it is not necessary to provide non-parametric correlation coefficients since the distribution of the variables examined is not significantly skewed and the data do not have outliers. Furthermore, only growth ratios will be used.

For all variables examined, the correlation- coefficient- zero- significance test is non-zero at $1 \%$ confidence level, except for Mineral Fuels, Lubricants and Related Materials (04) and the Total Assets and Policy Interest Rate, where the significance is, however, less than a 5\% confidence level and therefore, also relevant. Thus, the model is significantly good and, with one exception, it can be stated that there is only a $1 \%$ or $5 \%$ risk that there is no dependence between the export groups under review and selected central bank indicators. The results are shown in Table 3.

The table shows a basic statistical analysis of indicators characterizing the central bank and individual export industries. The Pearson correlation coefficient is calculated, the significance and the number of observations is given. In the case of the relations between Foreign Exchange Reserves and the export groups examined, significant direct dependence is identified in the Machinery and Transport Equipment (08), Miscellaneous Manufactured Articles (09) and Commodities and Transactions not Classified Elsewhere in the SITC (10) groups, the first two being the most important export groups in terms of volume. The Total Assets control variable achieves the strongest positive dependency of the same three export groups. 
Table 3. Pearson Correlation

\begin{tabular}{|c|c|c|c|c|c|c|c|c|c|}
\hline & $\begin{array}{l}\text { Foreign } \\
\text { reserves }\end{array}$ & exch & ange & Total asset & & & Policy inter & st rate & \\
\hline & $\begin{array}{l}\text { Pearson } \\
\text { Correlation }\end{array}$ & $\begin{array}{l}\text { Sig. } \\
(2- \\
\text { tailed) }\end{array}$ & $\mathrm{N}$ & $\begin{array}{l}\text { Pearson } \\
\text { Correlation }\end{array}$ & $\begin{array}{l}\text { Sig. } \\
(2- \\
\text { tailed) }\end{array}$ & $\mathrm{N}$ & $\begin{array}{l}\text { Pearson } \\
\text { Correlation }\end{array}$ & $\begin{array}{l}\text { Sig. } \\
(2- \\
\text { tailed) }\end{array}$ & $\mathrm{N}$ \\
\hline $\mathrm{VEX}_{1}$ & $.685^{* *}$ & 0.000 & 133 & $.789^{* *}$ & 0.000 & 133 & $-.610^{* *}$ & 0.000 & 133 \\
\hline $\mathrm{VEX}_{2}$ & $.750^{* *}$ & 0.000 & 133 & $.803^{* *}$ & 0.000 & 133 & $-.497^{* *}$ & 0.000 & 133 \\
\hline $\mathrm{VEX}_{3}$ & $.508^{* *}$ & 0.000 & 133 & $.592^{* * *}$ & 0.000 & 133 & $-.499^{* *}$ & 0.000 & 133 \\
\hline VEX $_{4}$ & $-.300^{* *}$ & 0.000 & 133 & $-.176^{*}$ & 0.042 & 133 & $-.217^{*}$ & 0.012 & 133 \\
\hline $\mathrm{VEX}_{5}$ & $.435^{* *}$ & 0.000 & 133 & $.557^{* * *}$ & 0.000 & 133 & $-.706^{* *}$ & 0.000 & 133 \\
\hline VEX $_{6}$ & $.793^{* *}$ & 0.000 & 133 & $.877^{* * *}$ & 0.000 & 133 & $-.543^{* *}$ & 0.000 & 133 \\
\hline $\mathrm{VEX}_{7}$ & $.650^{* *}$ & 0.000 & 133 & $.740^{* * *}$ & 0.000 & 133 & $-.406^{* *}$ & 0.000 & 133 \\
\hline $\mathrm{VEX}_{8}$ & $.834^{* *}$ & 0.000 & 133 & $.897^{* * *}$ & 0.000 & 133 & $-.455^{* *}$ & 0.000 & 133 \\
\hline $\mathrm{VEX}_{9}$ & $.833^{* *}$ & 0.000 & 133 & $.888^{* * *}$ & 0.000 & 133 & $-.497^{* *}$ & 0.000 & 133 \\
\hline$V E X_{10}$ & $.813^{* *}$ & 0.000 & 133 & $.886^{* *}$ & 0.000 & 133 & $-.584^{* *}$ & 0.000 & 133 \\
\hline
\end{tabular}

Source: Authors' representation based on Czech Statistical Office (2019)

In the case of the Policy Interest Rate, an indirect relationship is identified for all indicators with the most significant values for the export groups Animal and Vegetable Oils, Fats and Waxes (05), Food and Live Animals (01), Commodities and Transactions not Classified Elsewhere in the SITC (10), which however represent a rather minor and less important part of exports. Indeed, the indirect dependence of larger groups is also proved, but it is weaker and closer to independence.

This examination thus suggests that the hypothesis H01 would be confirmed, but the remaining two hypotheses $\mathrm{H} 02$ and $\mathrm{H} 03$ would have to be rejected. Further, regression analysis on given export groups will be used. The result for the first group Food and Live Animals (01) is given in Table 4.

Table 4. Regression coefficients with the dependent variable Food and Live Animals

\begin{tabular}{lrrrl}
\hline & Estimate & Std. Error & \multicolumn{1}{c}{ t } & Sig. \\
\hline (Constant) & -1.163 & 0.261 & -4.463 & 0.000 \\
\hline Foreign exchange reserves & -0.325 & 0.051 & -6.381 & 0.000 \\
\hline Total assets & 2.440 & 0.266 & 9.168 & 0.000 \\
\hline Policy interest rate & -0.064 & 0.017 & -3.671 & 0.000 \\
\hline
\end{tabular}

Source: Authors' representation based on Czech Statistical Office (2019) 
The table shows the regression coefficients, deviation and signifiers describing the relationships between central bank indicators and the selected export group. According to the hypothesis, it can be assumed that the monitored export groups depend on changes in foreign exchange interventions, which are reflected in the total assets of the Czech National Bank and also dependent on the Policy Interest Rate. Significance is zero, so we can reject the hypothesis that the effect of changes in foreign exchange interventions, total assets or interest rates is zero on the first group of export commodities. The coefficient of the determination of R-squared reaches a significant value of 0.796 and there is a significant percentage of common variability. Regression equations can be oversized as follows:

$$
V E X_{01 t}=-0.325 F E R_{t}+2.44 T A_{t}-0.064 P I R_{t}-1.163+\varepsilon
$$

A unit change or a one percent change in logarithm indicator the Foreign Exchange Reserves variable would result in a $0.325 \%$ decline in Food and Live Animals (01) exports. This is therefore the opposite effect to that expected. However, in the case of Total Assets, there is a positive relationship between this export group and the indicator. Thus, while the growth of Foreign Exchange Reserves would cause a decrease, it would also be reflected in the Central Bank's Total Assets and cause, according to regression coefficients, a re-growth in the monitored export group. A negative effect is also identified in the case of Policy Interest Rate growth, and this is assumed. Another export group, Beverages and Tobacco (02), again belongs to the group less significant in terms of value and share in total exports. The resulting regression analysis values are shown in Table 5.

Table 5. Regression coefficients with the dependent variable Beverages and Tobacco

\begin{tabular}{lrrrl}
\hline & Estimate & Std. Error & \multicolumn{1}{c}{ t } & Sig. \\
\hline (Constant) & -0.890 & 0.637 & -1.397 & 0.165 \\
\hline Foreign exchange reserves & -0.132 & 0.125 & -1.056 & 0.293 \\
\hline Total assets & 2.358 & 0.651 & 3.624 & 0.000 \\
\hline Policy interest rate & -0.124 & 0.043 & -2.916 & 0.004
\end{tabular}

Source: Authors' representation based on Czech Statistical Office (2019)

The table shows the regression coefficients, deviation and signifiers describing the relationships between central bank indicators and the selected export group.

In the case of foreign exchange reserves, the significance is $29.3 \%$ and therefore, we cannot reject the hypothesis of zero influence of foreign exchange interventions on the second group of monitored export commodities. In the case of Total Assets, the significance is in the required interval and the direct relationship is considerable. The indirect relationship between this export group and the Policy 
Interest Rate is significantly higher than in the previous case, and a unitary interest rate increase would result in a drop in the group of monitored commodities by 0.124 . The coefficient of determination, i.e. the extent to which the independent variables explain the dependent variables, is 0.687 and the common variability thus reaches a lower level than in the previous case.

The Arima process on the Beverages and Tobacco and Foreign exchange reserves indicators is used. The optimum time delay is 2 years. Results are shown in Table 6. Significance is zero and thus, a positive relationship between the indicators is identified.

Table 6. AR1 process, time delay 2 years, dependent variable Beverages and Tobacco

\begin{tabular}{|c|c|c|c|c|c|c|}
\hline & & & & Estimate & $\mathbf{t}$ & Sig. \\
\hline \multirow{2}{*}{$\begin{array}{l}\text { Beverages } \\
\text { and } \\
\text { Tobacco }\end{array}$} & \multirow{2}{*}{$\begin{array}{l}\text { No } \\
\text { Transformation }\end{array}$} & \multicolumn{2}{|l|}{ Constant } & 1.136 & 4.597 & 0.000 \\
\hline & & $\mathrm{AR}$ & Lag 1 & 0.866 & 18.895 & 0.000 \\
\hline \multirow{2}{*}{$\begin{array}{l}\text { Foreign } \\
\text { exchange } \\
\text { reserves }\end{array}$} & \multirow{2}{*}{$\begin{array}{l}\text { No } \\
\text { Transformation }\end{array}$} & Delay & & 2 & & \\
\hline & & Numerator & Lag 0 & 0.344 & 3.906 & 0.000 \\
\hline
\end{tabular}

Source: Authors' representation based on Czech Statistical Office (2019)

The table shows the AR1 model, the regression coefficients and signifiers describing the relationships between the selected central bank indicator and the selected export group. Time delay 2 years.

Table 7 is focused on the penultimate export group from the category characterized by a lower share of total exposure. These are Crude Materials, Inedible, Except Fuels (03). That means hides, skins and furskins, raw, oil-seeds and oleaginous fruits, crude rubber (including synthetic and reclaimed), cork and wood, pulp and waste paper, textile fibres (other than wool tops and other combed wool) and their wastes (not manufactured into yarn or fabric), crude fertilizers, other than those of division 56, and crude minerals (excluding coal, petroleum and precious stones), metalliferous ores and metal scrap, crude animal and vegetable materials, n.e.s.

Table 7. Regression coefficients with the dependent variable Crude Materials, Inedible, Except Fuels

\begin{tabular}{lrrrr}
\hline & Estimate & \multicolumn{1}{c}{ Std. Error } & \multicolumn{1}{c}{ t } & \multicolumn{1}{c}{ Sig. } \\
\hline (Constant) & 0.098 & 0.290 & 0.340 & 0.734 \\
\hline Foreign exchange reserves & -0.168 & 0.057 & -2.974 & 0.004 \\
\hline Total assets & 1.247 & 0.296 & 4.218 & 0.000 \\
\hline Policy interest rate & -0.045 & 0.019 & -2.308 & 0.023 \\
\hline
\end{tabular}

Source: authors' representation based on Czech Statistical Office (2019) 
The table shows the regression coefficients, deviation and signifiers describing the relationships between central bank indicators and the selected export group. Significance is below $5 \%$ in all three cases and we can reject the hypothesis that there is no relationship between the central bank's indicators under review and the given export group. In the case of the Policy Interest Rate, the significance is higher, but still below $5 \%$. Significance can be further reduced using the Arima process and the optimum time delay is 1 year. Data is illustrated in Table number 8 .

Table 8. AR1 process, time delay 1 year, dependent variable Crude Materials, Inedible, Except Fuels

\begin{tabular}{lllrrrr}
\hline & & & & Estimate & t & Sig. \\
\hline Crude Materials, & No & Constant & & 1.485 & 32534 & 0.000 \\
\cline { 2 - 5 } $\begin{array}{l}\text { Inedible, Except } \\
\text { Fuels }\end{array}$ & Transformation & AR & Lag 1 & 0.616 & 8.736 & 0.000 \\
\hline Policy interest rate & No & & & & & \\
& Transformation & Delay & & & \\
\cline { 3 - 5 } & & Numerator & Lag 0 & -0.115 & -3.396 & 0.001 \\
\hline
\end{tabular}

Source: Authors' representation based on Czech Statistical Office (2019)

The table shows the AR1 model, the regression coefficients and signifiers describing the relationships between the selected central bank indicator and the selected export group. Time delay 1 year.

However, the share of the explained variability in the overall variability, i.e. R Square, is only 0.472 in this case and, for the most part the export group, it is influenced by factors other than those extracted from the central bank. Given the nature of this group, other industries engaged in their processing abroad, as well as significant time delays following the commodity price vertical, may have a major impact on changes in the value of exports of this raw material.

The last export group with a lower export share is Mineral Fuels, Lubricants and Related Materials (04). The resulting values generated from the regression analysis are shown in Table 9.

Table 9. Regression coefficients with the dependent variable Mineral Fuels, Lubricants and Related Materials

\begin{tabular}{lrrrl}
\hline & Estimate & Std. Error & \multicolumn{1}{c}{ t } & \multicolumn{1}{c}{ Sig. } \\
\hline (Constant) & -0.452 & 0.306 & -1.478 & 0.142 \\
\hline Foreign exchange reserves & -0.430 & 0.060 & -7.186 & 0.000 \\
\hline Total assets & 1.959 & 0.313 & 6.269 & 0.000 \\
\hline Policy interest rate & 0.000 & 0.020 & 0.016 & 0.987 \\
\hline
\end{tabular}

Source: Authors' representation based on Czech Statistical Office (2019) 
The table shows the regression coefficients, deviation and signifiers describing the relationships between central bank indicators and the selected export group. Given the significance of the Policy Interest Rate, which reaches $98.7 \%$, we almost certainly cannot reject the hypothesis that the interest rate does not affect the monitored group of export commodities. Even with the subsequent use of the Arima process and the most optimum time delay of 5 years, the significance is still out of the required interval, as shown in Table 10.

Table 10. AR1 process, time delay 5 years, dependent variable Mineral Fuels, Lubricants and Related Materials.

\begin{tabular}{|c|c|c|c|c|c|c|}
\hline & & & & Estimate & $\mathbf{t}$ & Sig. \\
\hline \multirow{2}{*}{$\begin{array}{lr}\text { Mineral Fuels, } \\
\text { Lubricants and } \\
\text { Related Materials }\end{array}$} & No & Constant & & 1.304 & 16.204 & 0.000 \\
\hline & Transformation & AR & Lag 1 & 0.842 & 17.684 & 0.000 \\
\hline \multirow[t]{2}{*}{ Policy interest rate } & No & Delay & & 5 & & \\
\hline & Transformation & Numerator & Lag 0 & -0.055 & -1.047 & 0.297 \\
\hline
\end{tabular}

Source: Authors' representation based on Czech Statistical Office (2019)

The table shows the AR1 model, the regression coefficients and signifiers describing the relationships between the selected central bank indicator and the selected export group. Time delay 5 years.

In this case, the coefficient of determination, which is at a very low level of 0.377, is also distorted. Although the positive impact of the growth of Total Assets on this export group outweighs the negative relationship with the Foreign Exchange Reserves indicator, this group is greatly affected by the fact that it is based substantially on imports and significantly less on exports.

Another export group, Chemicals and Related Products (06), is one of the most important in terms of its share in exports and its possible changes due to the fact that changes in central bank indicators have already had a significant impact on other areas of the national economy. The resulting values are shown in Table 11.

Table 11. Regression coefficients with the dependent variable Chemicals and Related Products

\begin{tabular}{lrrrr}
\hline & Estimate & Std. Error & \multicolumn{1}{c}{ t } & \multicolumn{1}{c}{ Sig. } \\
\hline (Constant) & -0.901 & 0.204 & -4.420 & 0.000 \\
\hline Foreign exchange reserves & -0.243 & 0.040 & -6.089 & 0.000 \\
\hline Total assets & 2.119 & 0.208 & 10.169 & 0.000 \\
\hline Policy interest rate & -0.033 & 0.014 & -2.435 & 0.016 \\
\hline
\end{tabular}

Source: Authors' representation based on Czech Statistical Office (2019) 
The table shows the regression coefficients, deviation and signifiers describing the relationships between central bank indicators and the selected export group.

In this case, the significance is zero, i.e. an increase in Foreign Exchange Reserves by one unit will result in a decline in the value of the export group under review by 0.243 , while growth by one unit in Total Assets will lead to a growth of 2.119. The Policy Interest Rate again has an indirect relationship with the export group. Again, it is an import strongly oriented group and exports reach significantly lower values. In addition, this may be an important factor that eliminates the effect of domestic Policy Interest Rates. The equation is then written as follows:

$$
V E X_{06 t}=-0.243 F E R_{t}+2.119 T A_{t}-0.033 P I R_{t}-0.901+\varepsilon
$$

The relationship is confirmed by the common variability, which is $\mathrm{R}^{2}=0.858$. Therefore, there is a strong link between the development of the export group under review and these central bank indicators. Again, as shown, Foreign exchange reserves have the opposite effect to what is expected. However, as a result, as indicated by the Total Assets control variable, the effect is positive. This schism can be attributed to a sudden increase in Foreign Exchange Reserves, which did not translate to the extreme value of the Total Assets reaching higher orders, although they influenced them significantly in the period under review.

Another export group monitored was Manufactured Goods Classified Chiefly by Material (07). The data obtained from regression analysis are shown in Table 12.

Table 12. Regression coefficients with the dependent variable Manufactured Goods Classified Chiefly by Material

\begin{tabular}{lrrrr}
\hline & Estimate & \multicolumn{1}{c}{ Std. Error } & \multicolumn{1}{c}{ t } & \multicolumn{1}{c}{ Sig. } \\
\hline (Constant) & -0.643 & 0.196 & -3.277 & 0.001 \\
\hline Foreign exchange reserves & -0.231 & 0.038 & -6.023 & 0.000 \\
\hline Total assets & 1.661 & 0.201 & 8.280 & 0.000 \\
\hline Policy interest rate & 0.014 & 0.013 & 1.053 & 0.294 \\
\hline
\end{tabular}

Source: Authors' representation based on Czech Statistical Office (2019)

The table shows the regression coefficients, deviation and signifiers describing the relationships between central bank indicators and the selected export group.

In this case again, based on the resulting value of significance, we cannot reject the hypothesis that the interest rate does not affect the monitored group of export commodities. Again, there is some distortion of the Policy Interest Rate, which was part of the period under review to so-called technical zero, although initially declining and showing a gradual increase in the second part of the period under review. The actual $\mathrm{R}$ Square determination coefficient is still significant at 0.66 and there is common information between dependent and independent 
variables. The regression coefficients themselves for indicators with insignificance reach high values, influencing this monitored export industry. However, with the exclusion of interest rates, the regression equation will not be compiled. Significance can be reduced to zero again using the Arima process, with an optimum delay of 4 years, as shown in Table 13.

Table 13. AR1 process, time delay 4 years, dependent variable Manufactured Goods Classified Chiefly by Material

\begin{tabular}{llllrrr}
\hline & & & & Estimate & t & Sig. \\
\hline Manufactured & No & Constant & & 1.204 & 32.209 & 0.000 \\
\cline { 2 - 7 } $\begin{array}{l}\text { Goods Classified } \\
\text { Chiefly by Material }\end{array}$ & Transformation & AR & Lag 1 & 0.607 & 8.392 & 0.000 \\
\hline Policy interest rate & $\begin{array}{l}\text { No } \\
\text { Transformation }\end{array}$ & & Delay & & 4 & \\
\cline { 3 - 7 } & & Numerator & Lag 0 & -0.108 & -3.839 & 0.000 \\
\hline
\end{tabular}

Source: Authors' representation based on Czech Statistical Office (2019)

The table shows the AR1 model, the regression coefficients and signifiers describing the relationships between the selected central bank indicator and the selected export group. Time delay 4 years.

The most important export group in terms of its share in total exports is Machinery and Transport Equipment (08). For this sector, regression coefficient values are given in Table 14.

Table 14. Regression coefficients with the dependent variable Machinery and Transport Equipment

\begin{tabular}{lrrrl}
\hline & Estimate & Std. Error & \multicolumn{1}{c}{ t } & Sig. \\
\hline (Constant) & -0.949 & 0.224 & -4.234 & 0.000 \\
\hline Foreign exchange reserves & -0.188 & 0.044 & -4.292 & 0.000 \\
\hline Total assets & 1.943 & 0.229 & 8.486 & 0.000 \\
\hline Policy interest rate & -0.008 & 0.015 & -0.547 & 0.585
\end{tabular}

Source: Authors' representation based on Czech Statistical Office (2019)

The table shows the regression coefficients, deviation and signifiers describing the relationships between central bank indicators and the selected export group.

The relationship between the Policy Interest Rate and the monitored export group shows high significance and we do not reject the hypothesis that there is no relationship between these indicators. A high value and a share of $60 \%$ of total exports characterize this export industry and the value doubled in the period under review. With regard to stable growth and share in total exports, this export group is more influenced more by foreign factors, which is due to the connection of this sector 
to foreign capital and the situation on foreign markets. Given the importance of this group, the two other Foreign Exchange Reserves and Total Assets coefficients are high, the difference between the negative contribution of Foreign Exchange Reserves and the positive contribution of Total Assets to the growth of this export group is considerable, and the overall effect can be described as positive. Similarly, the common variability achieves a high value of $R^{2}=0.840$. With respect to this finding, a regression equation is compiled, omitting an inappropriate interest rate parameter. The regression equation is constructed as follows:

$$
V E X_{08 t}=-0.188 F E R_{t}+1.943 T A_{t}-0.949+\varepsilon
$$

The contradictory effect of Foreign Exchange Reserves and Total Assets will cause each unit to grow by a positive contribution to the value of this export group by 1.755 units. With the use of the Arima process and a time delay of 4 years, the negative relationship between Machinery and Transport Equipment and Policy Interest Rate is also shown. The results are in Table 15.

Table 15. AR1 process, time delay 4 years, the dependent variable Machinery and Transport Equipment

\begin{tabular}{lllllll}
\hline & & & & Estimate & t & Sig. \\
\hline Machinery and & No & Constant & & 1.437 & 15.119 & 0.000 \\
\cline { 3 - 7 } $\begin{array}{l}\text { Transport } \\
\text { Equipment }\end{array}$ & Transformation & AR & Lag 1 & 0.819 & 15.006 & 0.000 \\
\hline \multirow{2}{*}{ Policy interest rate } & $\begin{array}{l}\text { No } \\
\text { Transformation }\end{array}$ & Delay & & 4 & & \\
\cline { 3 - 7 } & Numerator & Lag 0 & -0.170 & -2.685 & 0.008 \\
\hline
\end{tabular}

Source: Authors' representation based on Czech Statistical Office (2019)

The table shows the AR1 model, the regression coefficients and signifiers describing the relationships between the selected central bank indicator and the selected export group. Time delay 4 years. The last export group is Miscellaneous Manufactured Articles (09), which also has a higher share in total exports and is also an important group. The data are shown in Table 16.

Table 16. Regression coefficients with the dependent variable Miscellaneous Manufactured Articles

\begin{tabular}{lrrrl}
\hline & Estimate & Std. Error & \multicolumn{1}{c}{ t } & \multicolumn{1}{l}{ Sig. } \\
\hline (Constant) & -0.855 & 0.341 & -2.507 & 0.013 \\
\hline Foreign exchange reserves & -0.135 & 0.067 & -2.026 & 0.045 \\
\hline Total assets & 2.053 & 0.349 & 5.891 & 0.000 \\
\hline Policy interest rate & -0.062 & 0.023 & -2.719 & 0.007 \\
\hline
\end{tabular}

Source: Authors' representation based on Czech Statistical Office (2019) 
The table shows the regression coefficients, deviation and signifiers describing the relationships between central bank indicators and the selected export group.

Although the significance of Foreign Exchange Reserves has seriously increased, it is still below the 5\% threshold. All three central bank indicators thus have an impact on this monitored export group. This is confirmed by the coefficient of common variability which, in this case, is 0.822 . The following regression equation is constructed:

$$
V E X_{09 t}=-0.135 F E R_{t}+2.053 T A_{t}-0.062 P I R_{t}-0.855+\varepsilon
$$

The percentage difference between the negative effect on this Foreign Exchange Reserves group and the positive Total Assets effect is in this case the most striking of all the groups examined. The link between Miscellaneous Manufactured Articles and Foreign Exchange Reserves is then better confirmed using the Arima process, with an optimum delay of 2 years, as shown in Table 17.

Table 17. AR1 process, time delay 2 years, dependent variable Miscellaneous Manufactured Articles

\begin{tabular}{|c|c|c|c|c|c|c|}
\hline & & & & Estimate & $\mathbf{t}$ & Sig. \\
\hline \multirow{2}{*}{$\begin{array}{l}\text { Miscellaneous } \\
\text { Manufactured Articles }\end{array}$} & \multirow{2}{*}{ No Transformation } & Constant & & 1.020 & 9.157 & 0.000 \\
\hline & & $\mathrm{AR}$ & Lag 1 & 0.734 & 12.049 & 0.000 \\
\hline \multirow{2}{*}{$\begin{array}{l}\text { Foreign exchange } \\
\text { reserves }\end{array}$} & \multirow{2}{*}{ No Transformation } & Delay & & 2 & & \\
\hline & & Numerator & Lag 0 & 0.259 & 6.219 & 0.000 \\
\hline
\end{tabular}

Source: Authors' representation based on Czech Statistical Office (2019)

The table shows the AR1 model, the regression coefficients and signifiers describing the relationships between the selected central bank indicator and the selected export group. Time delay 2 years. Finally, an analysis is carried out on the whole export group and the results are illustrated in Table 18.

Table 18. Regression coefficients with the dependent variable Total Export

\begin{tabular}{lrrrl}
\hline & Estimate & Std. Error & \multicolumn{1}{c}{ t } & Sig. \\
\hline (Constant) & -0.864 & 0.208 & -4.155 & 0.000 \\
\hline Foreign exchange reserves & -0.208 & 0.041 & -5.116 & 0.000 \\
\hline Total assets & 1.933 & 0.212 & 9.096 & 0.000 \\
\hline Policy interest rate & -0.014 & 0.014 & -0.978 & 0.330 \\
\hline
\end{tabular}

Source: Authors' representation based on Czech Statistical Office (2019)

The table shows the regression coefficients, deviation and signifiers describing the relationships between central bank indicators and the selected export group. 
Due to high significations for the Policy interest rate parameter, the Arima process is performed. The optimal time delay is then based on a 4 years time span. The data is illustrated in Table 19.

Table 19. AR1 process, time delay 4 years, dependent variable Total Export

\begin{tabular}{lllllll}
\hline & & & & Estimate & t & Sig. \\
\hline \multirow{2}{*}{ Total Export } & No & Constant & & 1.263 & 26.047 & 0.000 \\
\cline { 2 - 7 } & Transformation & AR & Lag 1 & 0.643 & 9.181 & 0.000 \\
\hline \multirow{2}{*}{$\begin{array}{l}\text { Policy interest } \\
\text { rate }\end{array}$} & No & Delay & & 4 & & \\
\cline { 2 - 7 } & Transformation & Numerator & Lag 0 & -0.116 & -3.757 & 0.000 \\
\hline
\end{tabular}

Source: Authors' representation based on Czech Statistical Office (2019)

The table shows the AR1 model, the regression coefficients and signifiers describing the relationships between the selected central bank indicator and the selected export group. Time delay 4 years.

To verify the accuracy of the hypotheses, an F- test was performed on these indicators. In the case of a relationship between the foreign direct investment and Total export indicators, the calculated values are as follows:

$$
\mathrm{F}_{\text {crtitical }}^{1}=0.749 ; \mathrm{F}_{\text {critical }}^{2}=1.334 ; \mathrm{F}^{1}=0.045 ; \mathrm{F}^{2}=22.379
$$

The one $\mathrm{F}$ value detected lies outside a given critical value interval. This means that we can reject the null hypothesis of no influence. Thus, at the level of significance $\alpha$ $=0.05$, we reject the null hypothesis of variance coincidence.

As far as the Total assets control indicator is concerned, the situation is reversed here and the values are calculated as follows:

$$
\mathrm{F}^{1} \text { crtitical }=0.749 ; \mathrm{F}_{\text {critical }}^{2}=1.334 ; \mathrm{F}^{1}=0.887 ; \mathrm{F}^{2}=1.127
$$

The two calculated F1 and F2 statistics are from an interval bounded by critical values, the test is statistically insignificant, we cannot reject the zero hypothesis. Thus, further to the calculation, a two-sample equal-variance t-test is used. By comparing the absolute value of the calculated statistic and the critical value for the duplex test $|-1.916|<1.969$, it is determined that the tested statistic does not exceed the critical value and, therefore, we accept the zero hypothesis. The same can be decided on the basis of p-value, i.e. $0.056>0.05$, and thus the p-value is greater than the selected test significance level, i.e. the value of the statistics corresponding to this p-value did not reach the critical value.

The latest hypothesis tested concerns the influence of Policy interest rate on Total export. Values found are as follows:

$$
\mathrm{F}_{\text {crtitical }}^{1}=0.749 ; \mathrm{F}_{\text {critical }}^{2}=1.334 ; \mathrm{F}^{1}=0,098 ; \mathrm{F}^{2}=10.194
$$

in addition, we can therefore reject the zero hypothesis of no influence at the level of significance $\alpha=0.05$. 


\section{Discussion}

Based on the research, the first hypothesis H01 is confirmed and it can be generally stated that this non-standard monetary policy had a positive effect on the export sector of the national economy and could thus support the growth of gross domestic product. In most of the monitored export groups, the level of common information reached a high value and therefore, the results can be considered conclusive and the influence is clearly proved. However, the impact of interventions on total exports loses its importance with the length of the intervention regime. The Policy Interest Rate itself has a much more pronounced inverse effect on the export industry. These results are quite consistent with the conclusions presented by Cavallino (2019) that foreign exchange interventions are not a substitute for standard monetary policy. However, it states that they could rather be complements. Guzman (2018) suggests that it would be more appropriate to combine direct interventions with other instruments (pricing, administrative, capital account management).

Hypothesis $\mathrm{H} 02$ is confirmed because this work identifies sectors that are affected by unconventional monetary policy, resp. supported relatively more and some less. Asymmetries are unambiguously created and certain export groups are favoured more than others. In terms of export groups with a smaller share in total exports, it is clearly the case of the Beverages and Tobacco group. On the other hand, the Mineral Fuels, Lubricants and Related Materials group has a weak negative impact on foreign exchange interventions. In the case of groups with a higher share in the total volume, the Miscellaneous Manufactured Articles and Machinery and Transport Equipment groups are clearly significantly more supported. On the contrary, Material group identifies the smallest contribution in the Manufactured Goods Classified Chiefly. The contributions are compared based on the relative expression of the contribution, not in the total volume, which would distort the result. However, Rodnyansky identifies a similar asymmetry in the banking market in terms of the portfolio distribution of banks with an emphasis on mortgages, and states that " $Q E$ had a differential effect on various types of financial institutions in the economy" (Rodnyansky, 2017, p. 35).

The last hypothesis $\mathrm{H} 03$ can be confirmed as the interest rate contributions in case of its change to individual export groups are significantly high. Its reduction has an impact on export growth. In the case of unit reduction, this impact is very significant, and so minor changes in the order of tens of basic points have a significant impact. Tümtürk (2019) confirms its importance for exchange rates in comparison with foreign exchange intervention policies. This channel is thus probably also the one that the significant influence of the interest rate spills into export industries. It is therefore necessary to reflect on a situation where, instead of a non-standard monetary policy, it would be more effective to continue working on an interest rate that has a much more significant impact on the entire export industry, even at the cost of a slight decrease to negative values. 
It should also be pointed out that, although the relationship generally seems to be between foreign exchange interventions and a general positive impact on the export industry, it can only be apparent because both time series are increasing. However, other supportive outcomes offered by correlation analysis or determination coefficients can largely refute this argument. In addition, the data are not adjusted for inflation, but since this is a homogeneous territorial unit and all-time series are examined over the same period, this shortcoming is also offset. For future research, it is possible to add impacts on the gross domestic product (GDP) or price level and mutual relations into discussion. Also, cross-border transfers of capital or services are not included and certainly deserve closer examination.

\section{Conclusions}

This article deals with the evaluation of foreign exchange interventions in the case of the Czech Republic with an impact on the export sector, classified according to the nature of the exported goods. Because of currency depreciation, according to economic theories, there should be an export advantage due to the lower prices of exported goods to foreign markets. However, the validity of this general economic theory may be limited by the negative market situation caused by the financial and subsequent economic crisis. Given the magnitude of the foreign exchange interventions and their value for this quantitative easing, the real impacts need to be examined.

The first hypothesis $\mathrm{H} 01$ is accepted and the paper confirmed the positive effect of foreign exchange intervention on the export sector, especially in the short term. The central bank is thus able to stimulate national economy and influence its structure and condition. However, the effect of the impacts is very asymmetric, and this directive intervention in the free market favours other sectors over others. This can cause fundamental distortions, which are not based on free market competition, but distort the market towards favoured sectors to the detriment of others, and market operators' incentives can be directed towards those favoured sectors. The second hypothesis $\mathrm{H} 02$ is accepted.

It is also essential that standard monetary policy remains the most effective, and these non-traditional instruments are certainly not substitutes. They can have a positive effect in the short term, but the key role of the standard interest rate instrument cannot be replaced and central banks should rather look for ways to continue using interest rates than adopt non-traditional instruments. This will enable them to respond better and more effectively to possible fluctuations in the economy; hypothesis $\mathrm{H} 03$ is accepted.

Acknowledgement: This study was supported by the Internal Grant Agency of Faculty of Economics and Management, Czech University of Life Sciences Prague. Project No. 2019A0006 - The effectiveness of short-term stabilization and long-term 
risks of non-standard CNB's monetary policy impacts on the national economy of the Czech Republic with an emphasis on selected sectors.

\section{References}

Adler, G. and Camilo, E.T. (2011), Foreign exchange intervention: a shield against appreciation winds?, IMF Working Paper 11/165.

Adler, G., Lisack, N. and Mano, R.C. (2019), Unveiling the effects of foreign exchange intervention: A panel approach, Emerging Markets Review, 40(C), pp. 1-1. https://doi.org/10.1016/j.ememar.2019.100620

Bauer, M.D. and Rudebusch, G.D. (2014), The signaling channel for federal reserve bond purchases, International Journal of Central Banking, 10(3), pp. 233-89. https://doi.org/10.24148/wp2011-21

Beine, M. (2004), Conditional Covariances and Direct Central Bank Interventions in the Foreign Exchange Markets, Journal of Banking \& Finance, 28(6), pp. 1385-1411. https://doi.org/10.1016/S0378-4266(03)00124-9

Blanchard, O., de Carvalho Filho, I. and Adler, G. (2015), Can Sterilized Foreign Exchange Intervention Stem Exchange Rate Pressures from Global Capital Flow Shocks?, Working Paper Series WP15-18, Peterson Institute for International Economics https://doi.org/10.5089/9781513585840.001

Cavallino, P. (2019), Capital Flows and Foreign Exchange Intervention, American Economic Journal: Macroeconomics, 11(2), pp. 127-170. https://doi.org/10.1257/mac.20160065

Chodorow, R.G. (2014), Effects of unconventional monetary policy on financial institutions, Brookings Papers on Economic Activity, (1), pp. 155-227. https://doi.org/10.1353/eca.2014.0003

Chutasripanich, N. and Yetman, J. (2015), Foreign exchange intervention: strategies and effectiveness, BIS Working Paper No. 499.

Cicek, M. (2014), An Evidence for Ineffectiveness of Central Bank Foreign Exchange Interventions from Turkey, Journal of Applied Finance \& Banking, 4(4), pp. 39-54.

Colacito, R. and Croce, M. (2011), Risks for the Long Run and the Real Exchange Rate, Journal of Political Economy, 119(1), pp. 153-181. https://doi.org/doi.org/10.1086/659238

Cottrell, A. (2018), Notes on the Taylor Rule, Wake Forest University.

Czech National Bank (2019), The main instruments of monetary policy: History of settings, Prague (retrieved from https://bit.ly/2KkRHv0).

Czech Statistical Office (2019), Metodické vysvětlivky $k$ databázi zahraničního obchodu $v$ príhraničním pojetí [Methodological notes to the database of foreign trade in the border concept], Praha (retrieved from https://www.czso.cz/csu/czso/zo).

Damill, M. (2015), Macroeconomic Policy in Argentina During 2002-2003, Comparative Economic Studies, 57, pp. 369-400. 
Daude, C., Yeyati, E.L. and Nagengast, A.J. (2016), On the effectiveness of exchange rate interventions in emerging markets, Journal of International Money and Finance 64(C), pp. 239-261.

Dominguez, K.M. and Frankel, J.A. (1993), Does foreign-exchange intervention matter? The portfolio effect, The American Economic Review, 83(5), pp. 1356-1369 (retrieved from https://www.jstor.org/stable/2117567).

Farhi, E. and Werning, I. (2012), Dealing with the trilemma: Optimal capital controls with fixed exchange rates, Technical Report, National Bureau of Economic Research. https://doi.org/10.3386/w18199

Fawley, B. and Neely, C. (2013), Four stories of quantitative easing, Federal Reserve Bank of St. Louis Review, 95(1), pp. 51-88. https://doi.org/10.20955/r.95.51-88

Fratzscher, M., Gloede, O., Menkhoff, L., Sarno, L. and Stöhr, T. (2019), When is foreign exchange intervention effective? Evidence from 33 countries, American Economic Journal: Macroeconomics, 11(1), pp. 132-56. https://doi.org/10.1257/mac.20150317

Frenkel, R. and Rapetti, M. (2014), The real exchange rate as a target of macroeconomic policy, MPRA Paper 59335, University Library of Munich, Germany.

Fukuda, S.I. and Doita, T. (2016), Unconventional monetary policy and its external effects: Evidence from Japan's exports, The Developing Economies, 54(1), pp. 59-79. https://doi.org/10.1111/deve.12094

Gagnon, J., Raskin, M., Remache, J. and Sack, B. (2011), The financial market effects of the Federal Reserve's large-scale asset purchases, International Journal of Central Banking, 7(1), pp. 3-43 (retrieved from https://www.ijcb.org/journal/ijcb11q1 a1.htm).

Georgiadis, G. (2014), Towards an explanation of cross-country asymmetries in monetary transmission, Journal of Macroeconomics, 39, pp. 66-84. https://doi.org/10.1016/j.jmacro.2013.10.003

Georgiadis, G. (2015), Examining asymmetries in the transmission of monetary policy in the euro area: evidence from a mixed cross-section global VAR model, Eur. Econ. Rev., 75, pp. 195-215. https://doi.org/10.1016/j.euroecorev.2014.12.007

Guzman, M., Ocampo, J.A. and Stiglitz, J.E. (2018), Real exchange rate policies for economic development, World Development, 110, pp. 51-62. https://doi.org/10.1016/j.worlddev.2018.05.017

Haas, C. and Taft, T.Y. (2017), Quantitative Easing and Asset Bubbles in a Stock-flow Consistent Framework, Levy Economics Institute: 897. https://doi.org/10.2139/ssrn.3100905

Hendl, J. (2012), Kvalitativní výzkum: základní teorie, metody a aplikace 3 [Qualitative research: basic theories, methods and applications], Praha: Portál.

Inoue, A. and Rossi, B. (2018), The effects of conventional and unconventional monetary policy: A new approach, Working paper (retrieved from: http://hdl.handle.net/10230/44710). 
Karnit, F. and Shpitzer, A. (2013), Rethinking exchange rate policy in a small open economy: the Israeli experience during the great recession, BIS Papers chapters, in: Bank for International Settlements (ed.), Sovereign risk: a world without risk-free assets? 73, pp. 189-204, Bank for International Settlements (retrieved from https://EconPapers.repec.org/RePEc:bis:bisbpc:73-14).

Korinek, A. (2011), The new economics of prudential capital controls: A research agenda, IMF Economic Review, 59(3), pp. 523-561. https://doi.org/10.1057/imfer.2011.19

Lutz, C. (2015), The impact of conventional and unconventional monetary policy on investor sentiment, Journal of Banking \& Finance, 61, pp. 89-105. https://doi.org/10.1016/j.jbankfin.2015.08.019

Missio, F.J., Jayme, Jr. F.G., Britto, G. and Luis Oreiro, J. (2015), Real exchange rate and economic growth: new empirical evidence, Metroeconomica, 66(4), pp. 686-714. https://doi.org/10.1111/meca.12087

Montoro, C. and M. Ortiz. (2016), Foreign exchange intervention and monetary policy design: a market microstructure analysis, Working Papers 2016-008, Banco Central de Reserva del Perú.

Palley, T.I. (2014), Monetary policy in the US and EU after quantitative easing: the case for asset based reserve requirements (ABRR), Real World Economic Review, 68, pp. 2-9.

Rapetti, M. (2013), Macroeconomic policy coordination in a competitive real exchange rate strategy for development, Journal of Globalization and Development, 3(2), pp. 1-31. https://doi.org/10.1515/jgd-2012-0009

Rodnyansky, A. and Darmouni, O.M. (2017), The Effects of Quantitative Easing on Bank Lending Behavior, The Review of Financial Studies, 30(11), pp. 3858-3887. https://doi.org/10.1093/rfs/hhx063

Rose, A.K. (2018), Currency wars? Unconventional Monetary policy does not stimulate exports, No. w24817, National Bureau of Economic Research (retrieved from: http://www.nber.org/papers/w24817).

Serati, M. and Venegoni, A. (2019), The cross-country impact of ECB policies: Asymmetries in-Asymmetries out?, Journal of international money and finance, 90, pp. 118-141. https://doi.org/10.1016/j.jimonfin.2018.09.008

Taylor, J.B. (2000), Low inflation, pass-through and the pricing power of firms, European Economic Review, 44(7), pp. 1389-1408. https://doi.org/10.1016/S00142921(00)00037-4

Tümtürk, O. (2019), Foreign Exchange Intervention and Exchange Rate Volatility: Evidence from Turkey, Anadolu Üniversitesi Sosyal Bilimler Dergisi, 19(2), pp. 49-64. https://doi.org/10.18037/ausbd.566685

Wang, W., Le, D.T. and Park, H. (2020), Is Foreign Exchange Intervention a Panacea in Diversified Circumstances? The Perspectives of Asymmetric Effects, Sustainability, 12(7), pp. 1-20. https://doi.org/10.3390/su12072913

Zamrazilová, E. (2014), Měnová politika: krátkodobá stabilizace versus dlouhodobá rizika, Politická ekonomie, 62(1), pp. 3-31. https://doi.org/10.18267/j.polek.935 